Canadian Oncology

Nursing Journal

Revue canadienne

de soins infirmiers

en oncologie

Volume 31, Issue 1 • Winter 2021

elSSN: 2368-8076 


\title{
Reducing emergency department utilization for outpatient acute cancer symptoms: An integrative review on the advent of urgent cancer clinics
}

\author{
by Tammy L. Patel, Shelley Raffin Bouchal, Catherine M. Laing, and Stephanie Hubbard
}

\begin{abstract}
The purpose of this integrative literature review was to identify nursing research opportunities related to outpatient acute cancer symptom management within emerging urgent cancer clinics (UCCs). Patients with acute cancer symptoms (e.g., fevers, gastrointestinal disturbances, or uncontrolled pain) from ambulatory settings predominantly rely on emergency departments (EDs) for assessment and treatment. However, this model of care is no longer sustainable and emphasizes healthcare system inefficiencies. Urgent cancer clinics allow patients to have these symptoms treated by oncology experts within ambulatory cancer centres. Unfortunately, limited research on urgent cancer clinics both operationally and experientially makes it difficult for others to adopt this new model of care. The core questions that guided this integrative review were: 1) What is the state of the science regarding UCCs, and what differences exist when compared to EDs in the management of outpatient acute cancer symptoms? and 2) Where do UCCs exist around the world, and what is understood about UCCs related to clinic operations and staffing models?
\end{abstract}

Keywords: urgent cancer clinics, outpatient oncology care, cancer, symptoms

\section{AUTHOR NOTES \\ Tammy L. Patel, RN, MN student, Faculty of Nursing, University of Calgary and Tom Baker Cancer Centre, Alberta Health Services}
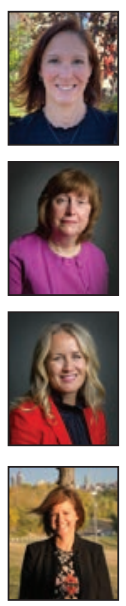

Shelley Raffin Bouchal, RN, PhD, Associate Professor, Faculty of Nursing, University of Calgary

Catherine M. Laing, RN, PhD, Associate Professor and Associate Dean Undergraduate Programs, Faculty of Nursing, University of Calgary

Stephanie Hubbard, RN, MNNP, Tom Baker Cancer Centre, Alberta Health Services.

Correspondence concerning this article should be addressed to: Tammy L. Patel, c/o Dr Shelley Raffin Bouchal, Associate Professor, Faculty of Nursing, University of Calgary, Professional Faculties Building 2270, 2500 University Dr NW, Calgary, AB T2N $1 \mathrm{~N} 4$.

Email: tammy.patel@ucalgary.ca

DOI: $10.5737 / 236880763112235$
$\Delta \mathrm{s}$ documented in the literature, a significant proportion 1 of cancer-related healthcare costs are associated with unplanned emergency department (ED) visits and subsequent hospital admissions (Colligan et al., 2017; Hassett et al., 2006; McKenzie et al., 2011). The yearly estimate for cancer-related ED visits in the USA is $3 \%$ (or 1 to 3 million visits) of all ED admissions (Cooksley \& Rice, 2017); and more than half of these ED visits will result in hospitalization according to a systematic review of 18 studies performed by Vandyk et al. (2012). A similar large-scale study on breast cancer in the USA found that $51 \%$ of patients will have one hospitalization or ED visit during their first year of treatment (Hassett et al., 2006). A study conducted in Calgary reported similar ED utilization rates by patients with cancer; 1,881 patients made 4,623 ED visits between July 2007 and September 2011 (Prystajecky et al., 2012). Furthermore, improved cancer survival rates have also accounted for the increasing burden on global healthcare expenditures (Young et al., 2016).

With increasing rates of cancer diagnoses annually and the expenses associated with unplanned ED admissions and hospitalizations, innovation in the delivery of cost-effective patient care is imperative. In Canada, the rate of cancer diagnoses over the past 35 years has increased from 89,200 in 1984 to 220,200 in 2019 equating to an average annual increase of 7\% (Canadian Cancer Statistics Advisory Committee, 2019). Meanwhile, the USA reported 499,000 cancer-related ED visits in 2007 at a total cost of $\$ 777.24$ million USD with an average cost of $\$ 1,558$ per ED visit (Mayer et al., 2011). Also in the USA, "the cost of a 2-3 day hospitalization stay with IV hydration and antiemetics is about \$8,729” (Mason et al., 2013, p. 585). In stark contrast, an outpatient visit with a nurse practitioner and administration of IV hydration and antiemetics averages only \$197 USD (Mason et al., 2013).

Emergency department resources (i.e., space, staff, and time) remain fixed, which may lead to immunocompromised patients with cancer facing extended wait times and increased risk of exposure to pathogens. Likewise, the conventional Canadian Emergency Department Triage and Acuity Scale (CTAS) does not accurately capture the unique needs of these patients as shown in Table 1. For example, a fever should be treated as a medical emergency in patients with cancer but CTAS assigns fever a level three (on a scale of urgency from one to five) with ideal wait times of up to 30 minutes; potentially putting these patients at increased risk of sepsis and mortality (Cooksley \& Rice, 2017; Trip et al., 2011). Many studies identified the most prevalent symptoms of patients with cancer who present to EDs as pain, fever, respiratory symptoms, 


\begin{tabular}{|c|c|c|}
\hline \multicolumn{3}{|c|}{$\begin{array}{l}\text { Table 1. Canadian emergency department Triage and Acuity Scale } \\
\text { (CTAS) }\end{array}$} \\
\hline CTAS Level & $\begin{array}{l}\text { Time to } \\
\text { Physician }\end{array}$ & Definitions \& Examples \\
\hline 1 - Resuscitation & Immediately & $\begin{array}{l}\text { Conditions that are a threat } \\
\text { to life or limb (e.g., cardiac } \\
\text { arrest, major trauma) }\end{array}$ \\
\hline 2 - Emergent & $\leq 15 \mathrm{mi}$ & $\begin{array}{l}\text { Conditions that are a } \\
\text { potential threat to life or limb } \\
\text { (e.g., spinal cord compression, } \\
\text { chest pain) }\end{array}$ \\
\hline 3 - Urgent & $\leq 30$ minutes & $\begin{array}{l}\text { Conditions that could } \\
\text { progress to a serious problem } \\
\text { requiring emergency } \\
\text { intervention (e.g., mild } \\
\text { respiratory distress, vomiting } \\
\text { \&/or nausea) }\end{array}$ \\
\hline 4 - Less Urgent & $\leq 60$ minutes & $\begin{array}{l}\text { Conditions that would benefit } \\
\text { from medical intervention } \\
\text { or reassurance within one to } \\
\text { two hours (e.g., urinary tract } \\
\text { infection, constipation) }\end{array}$ \\
\hline 5 - Non-Urgent & $\leq 120$ minutes & $\begin{array}{l}\text { Conditions that could be dealt } \\
\text { with in a GP clinic or walk-in } \\
\text { clinic (e.g., dressing changes, } \\
\text { suture removal) }\end{array}$ \\
\hline \multicolumn{3}{|c|}{$\begin{array}{l}\text { Note. Adapted from "Utilizing the Canadian emergency } \\
\text { department Triage and Acuity Scale (CTAS) in an oncology urgent } \\
\text { care clinic: The university health network experience." By K. Trip, } \\
\text { A. Boloorchi, \& H. Berman, 2011, Canadian Oncology Nursing } \\
\text { Journal, 21(1), p. } 52 \text {. }\end{array}$} \\
\hline
\end{tabular}

and gastrointestinal disturbances (Clarke et al., 2015; Cooksley \& Rice, 2017; Hassett et al., 2006; Livingston et al., 2011; Majem et al., 2007; Mayer et al., 2011; McKenzie et al., 2011; Meisenberg et al., 2014; Prystajecky et al., 2012; Ruegg, 2013; Sitzes-Determann, 2009; van der Meer et al., 2016; Vandyk et al., 2012). The consistent, predictable, and non-emergent nature of these symptoms offers potential for improved ambulatory services aimed at minimizing ED presentations.

\section{MANAGING OUTPATIENT ACUTE CANCER SYMPTOMS}

Within ambulatory cancer centres, the focus for cancer-related symptom management revolves around three strategies patient education, prevention, and telephone support (Young et al., 2016). Unfortunately, for some outpatients, acute cancer symptoms (e.g., fever, gastrointestinal disturbances, or uncontrolled pain) remain too severe for self-care strategies at home and require urgent medical attention. Across the continents, ambulatory cancer centres have historically utilized EDs to manage the acute unmet needs of patients with cancer (Young et al., 2016). As demonstrated by Prystajecky et al. (2012), the introduction of 24-hour telephone support at Calgary's ambulatory cancer centre was associated with a significant decrease of $32 \%$ in ED presentations over a 4-month period. Despite this telephone support demonstrating a decrease in ED presentations, a considerable number of patients with cancer continued to require in-person medical attention (Prystajecky et al., 2012).

As suggested by Colligan et al. (2017), "19-23\% of ED visits and hospitalizations for cancer patients are potentially avoidable" (p. 873) and their presenting symptoms would be better managed in ambulatory settings. Newly emerging urgent cancer clinics (UCCs) are specifically designed for outpatients experiencing non-emergent, acute cancer symptoms, and provide this alternate ambulatory environment. These UCCs are conveniently located within existing ambulatory cancer centres with the dual purpose of diverting patients away from EDs and ensuring cancer needs are met in one location by oncology experts. Furthermore, UCCs also allow patients with cancer to be accurately triaged based on the acuity of their oncologic emergency (Trip et al., 2011), thereby improving patient safety while embracing a patient-centred approach to care. The benefits of UCCs supports adopting this new comprehensive model of care while retiring ambulatory cancer centres' outdated reliance on EDs.

\section{PURPOSE}

The purpose of this integrative literature review was to determine the extent and types of research conducted to compare UCCs and EDs in the provision of outpatient acute cancer symptom management. A broad understanding of the literature helps pinpoint knowledge gaps and identify potential research topics. Specifically, this review provided the basis for formulating a graduate nursing research study question regarding UCCs.

\section{METHODS}

An integrative literature review was initiated to help provide historical relevance for shifting practice away from the ED model of care for oncology patients towards a comprehensive model of care with UCCs. Integrative reviews offer an alternative approach to researchers studying broad topics or research questions while allowing for simultaneous inclusion of various study designs, and article types - an important consideration for evidence-based practice in nursing (Whittemore \& Knafl, 2005). Synthesizing experimental and non-experimental studies contributes to fully understanding the phenomenon of interest (Whittemore \& Knafl, 2005). In addition, "the multiplicity of purposes has the potential to result in a comprehensive portrayal of complex concepts, theories, or healthcare problems of importance to nursing" (Whittemore \& Knafl, 2005, p. 548). The methods outlined in the Whittemore and Knafl (2005) integrative review framework includes five stages: 1) problem identification, 2) literature search, 3) data evaluation, 4) data analysis, and 5) data presentation. 


\section{Problem Identification}

The core research questions that guided this integrative literature review were:

1. What is the state of the science regarding UCCs, and what differences exist when compared to EDs in the management of outpatient acute cancer symptoms?

2. Where do UCCs exist around the world, and what is understood about UCCs related to clinic operations and staffing models?

\section{Literature Search}

In consultation with a research librarian and scientific writer - for coaching on search strategy, interface and database navigation, and Endnote usage - the first author developed and conducted a robust search strategy. The search strategy process included mapping search terms to subject headings, using truncation and wild cards, and using Boolean operators across each database. After several initial iterative searches were conducted, the following successful search terms were used for each data interface: ("oncology" OR "cancer") AND ("emergency" OR "acute” OR "urgent” OR "rapid”) AND ("clinic" OR "center” OR “centre” OR "department”) AND (“treatment” OR “care” OR “management”) AND ("outpatient” OR "ambulatory" OR "comprehensive" OR "community") AND “symptom*”.
All literature was identified using a variety of sources including electronic databases and reference lists, as well as grey literature from ProQuest, Google Scholar, and the internet. The search strategy avoided date restrictions since the topic of study only recently emerged. The integrative review consisted of searches from four online databases including: CINAHL $(n=127)$, MEDLINE $(n=704)$, PubMed $(n=907)$, and ProQuest Theses \& Dissertations Global $(n=13)$. The most recent search was conducted in October 2018.

The literature obtained from this search strategy was reviewed by the first author as required by her nursing graduate program. As summarized in Figure 1, the online database search strategy identified 1,738 articles while other sources revealed additional relevant articles $(n=16)$, including webbased resources and scanned reference lists, therefore returning a total of 1,754 literature sources. Duplicates $(n=35)$ were systematically removed during article title and abstract screening while the remaining titles and abstracts $(n=1,719)$ were scanned for suitability based on inclusion and exclusion criteria described below. A final 66 full-text articles were assessed for inclusion eligibility. Seventeen literature sources were included in the final integrative review based on adequately addressing the core questions and meeting all inclusion criteria.

Figure 1. Search Strategy Flow Diagram

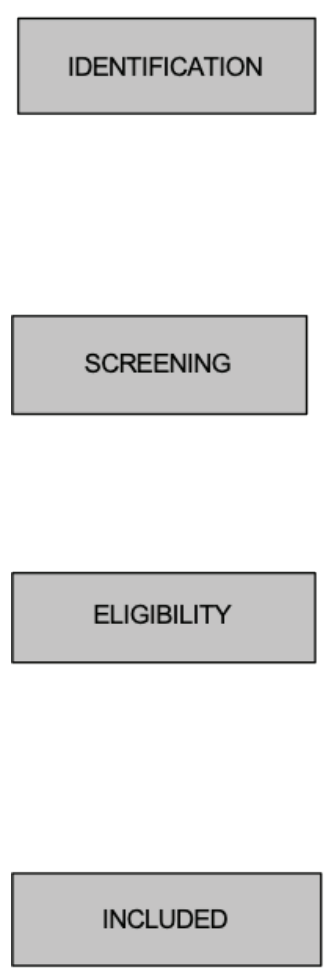

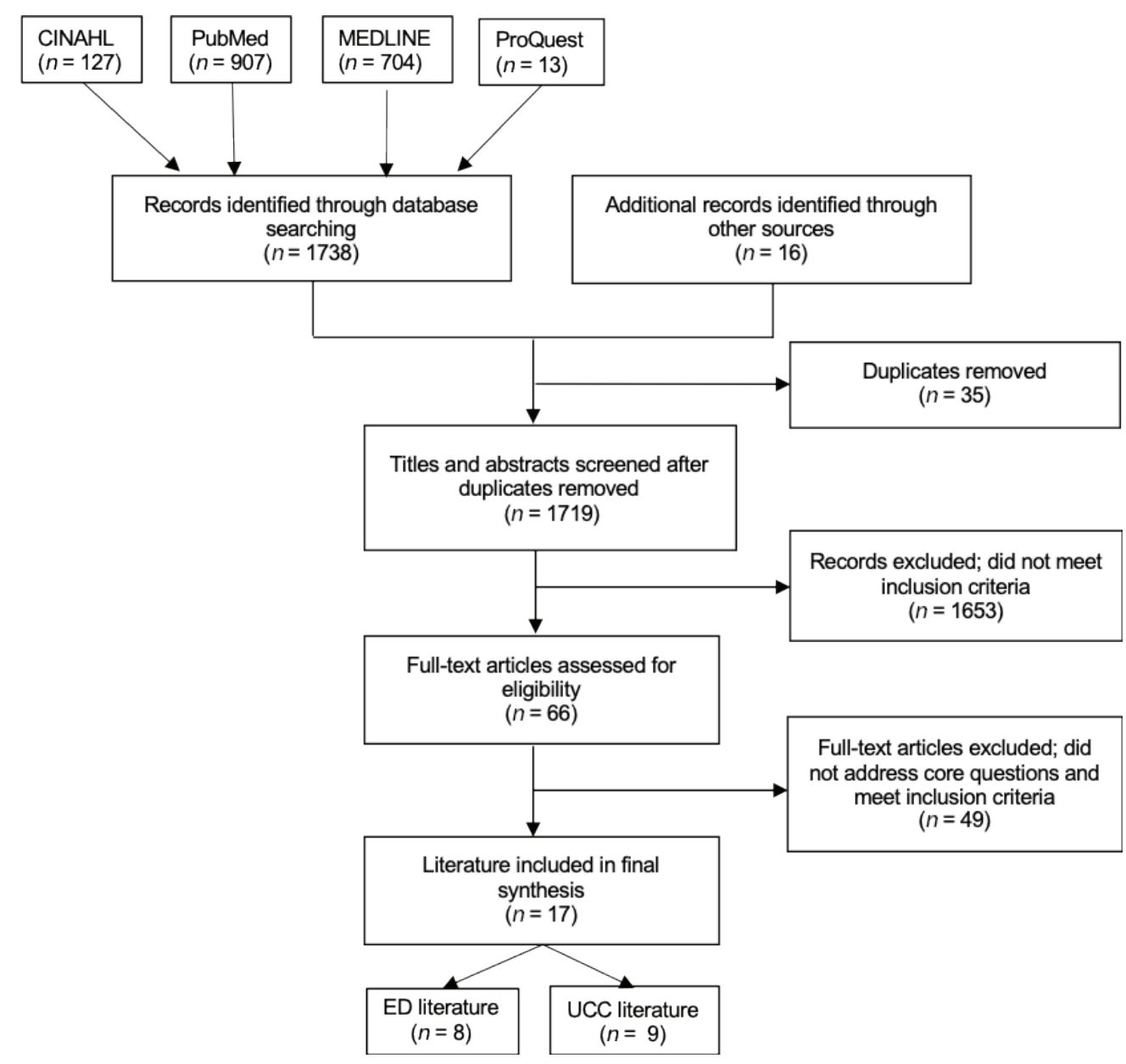


To determine relevant sources, the criteria used for article inclusion in this integrative review comprised: 1) peer-reviewed publications with full text available; 2) studies published in the English language; and 3) studies with a focus on patients who utilize either EDs or UCCs for acute cancer symptom management. The final exclusion criteria, however, emerged during the systematic screening of full-text articles. Articles were excluded based on the following criteria: 1 ) studies with a focus on palliative care patients with advanced cancer; 2) studies with a focus on paediatric patients with cancer; and 3) studies with a focus on the processes of emergency departments or community services (i.e., homecare) for patients with cancer since these processes are not generalizable to the Canadian healthcare system.

\section{Data Evaluation}

Each literature source meeting inclusion criteria and addressing a core question underwent critical appraisal by the first author using two Specialist Unit for Review of Evidence (SURE) (2018a, 2018b) checklists with criteria as represented in Tables 2 and 3. The final 17 literature sources were divided into two checklist tables specific to either qualitative (Table 2) or quantitative cohort studies (Table 3). The healthcare setting (i.e., ED versus UCC) for each study was also highlighted within each table. Each literature source was appraised for clarity regarding study purpose, methodological quality, precision, and external validity. Although each study had limitations, most ranked medium to high quality and none were excluded from this review. Additionally, studies of lower quality were
Table 2. Critical Appraisal of Qualitative Studies

\begin{tabular}{|c|c|c|}
\hline & $\begin{array}{l}\text { Qualitative } \\
\text { Study }\end{array}$ & Grey Literature \\
\hline Checklist & 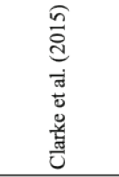 & 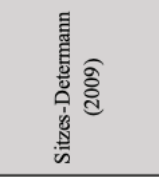 \\
\hline $\begin{array}{l}\text { Does the study address a clearly } \\
\text { focused question/hypothesis? }\end{array}$ & Yes & Yes \\
\hline $\begin{array}{l}\text { Is the choice of qualitative } \\
\text { method appropriate? }\end{array}$ & Yes & Yes \\
\hline $\begin{array}{l}\text { Is the sampling strategy clearly } \\
\text { described? }\end{array}$ & Yes & Yes \\
\hline $\begin{array}{l}\text { Is the method of data collection } \\
\text { well described? }\end{array}$ & Yes & Yes \\
\hline $\begin{array}{l}\text { Is the relationship between the } \\
\text { researcher(s) and participants } \\
\text { exlplored? }\end{array}$ & No & No \\
\hline $\begin{array}{l}\text { Are ethical issues explicitly } \\
\text { discussed? }\end{array}$ & Yes & Yes \\
\hline $\begin{array}{l}\text { Is the data analysis/interpretation } \\
\text { process described and justified? }\end{array}$ & Yes & Yes \\
\hline Are the findings credible? & Yes & Yes \\
\hline $\begin{array}{l}\text { Is any sponsorship/conflict of } \\
\text { interest reported? }\end{array}$ & No & No \\
\hline $\begin{array}{l}\text { Did the authors identify any } \\
\text { limitations? }\end{array}$ & Yes & No \\
\hline ED literature & & \\
\hline UCC literature & & \\
\hline
\end{tabular}

Note. Adapted from "Questions to assist with the critical appraisal of qualitative studies." By Specialist Unit for Review Evidence (SURE), 2018, Available at: https://www.cardiff.ac.uk/__data/assets/pdf_ file/0007/1142971/SURE-CA-form-for-Qualitative_2018.pdf

Table 3. Critical Appraisal of Quantitative Cohort Studies

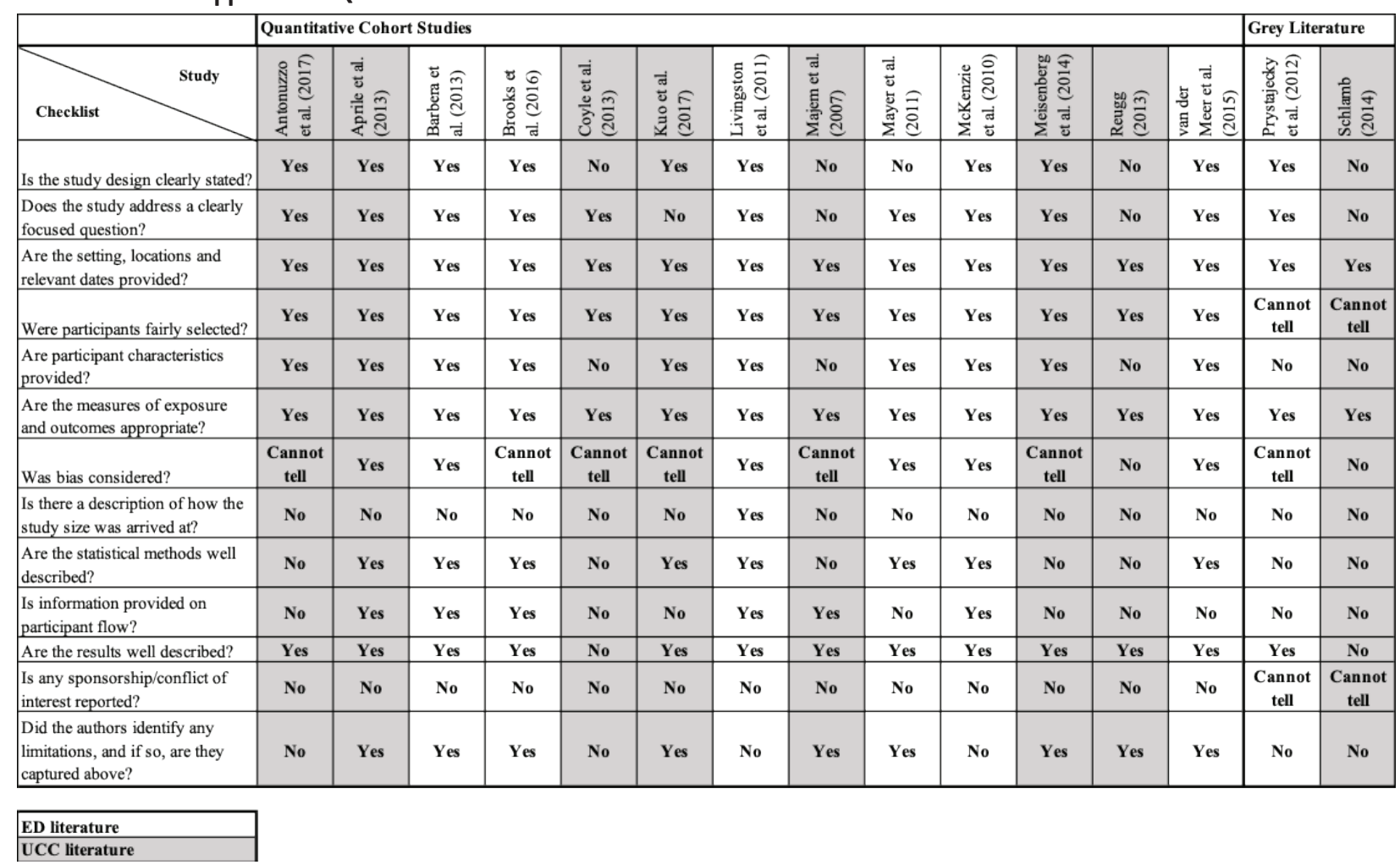

Note. Adapted from "Questions to assist with the critical appraisal of cohort studies." By Specialist Unit for Review Evidence (SURE), 2018, Available at: https://www.cardiff.ac.uk/_data/assets/pdf_file/0006/1142997/SURE-CA-form-for-Cohort_2018.pdf 
cited less frequently to account for decreased external validity. It is recognized by Whittemore and Knafl (2005) "that evaluating quality of primary sources in an integrative review is complex" (p. 550). Therefore, the critical appraisal tools chosen for this review aimed to ensure applicability for each checklist across all study designs while also remaining relevant to the included grey literature.

\section{Data Analysis}

The intent of this review was to develop an improved understanding of UCCs as a potential ambulatory setting and alternative to EDs for outpatient acute cancer symptom management. Each full-text article was read to extract and record detailed data into a standardized Excel spreadsheet. For improved clarity of information and to assist with analysis, data were split into two subgroups (Whittemore \& Knafl, 2005). These subgroups are each represented by separate data extraction tables, one inclusive of all ED literature sources (Table 4), and one inclusive of all UCC literature sources (Table 5). Study data extracted from ED literature were summarized according to authors (year) and location, purpose of study, study design, sample, study findings, and limitations.

\begin{tabular}{|c|c|c|c|c|c|}
\hline \multicolumn{6}{|c|}{ ED Literature } \\
\hline $\begin{array}{l}\text { Authors } \\
\text { (Year) } \\
\text { Location }\end{array}$ & Purpose of Study & Study Design & Sample & Study Findings & Limitations \\
\hline $\begin{array}{l}\text { Barbera } \\
\text { et al. } \\
\text { (2013) } \\
\text { Canada }\end{array}$ & $\begin{array}{l}\text { To determine the } \\
\text { relationship between } \\
\text { Edmonton Symptom } \\
\text { Assessment System } \\
\text { (ESAS) score severity } \\
\text { and likelihood of ED } \\
\text { presentation within } 7 \\
\text { days of assessment. }\end{array}$ & $\begin{array}{l}\text { Quantitative } \\
\text { retrospective cohort } \\
\text { study of ambulatory } \\
\text { and community- } \\
\text { based cancer } \\
\text { patients in Ontario } \\
\text { between } 2007 \text { and } \\
2009 \text {. }\end{array}$ & $\begin{array}{l}n=45,118 \text { unique patients. } \\
\text { Included all patients } \\
\text { evaluated between date } \\
\text { of diagnosis and date of } \\
\text { death or last follow-up at } \\
\text { their first assessment with } \\
\text { an ESAS tool. Included } \\
\text { all regions of province } \\
\text { and any cancer diagnosis, } \\
\text { of any age receiving any } \\
\text { treatment with curative or } \\
\text { palliative intent. } \\
\text { Excluded 2,693 patients } \\
\text { due to incomplete } \\
\text { symptom data, invalid or } \\
\text { missing health insurance } \\
\text { number, or no link to the } \\
\text { Ontario Cancer Registry. }\end{array}$ & $\begin{array}{l}1,732(3.8 \%) \text { patients made an ED visit } \\
\text { within } 7 \text { days of ESAS assessment, } 72 \% \\
\text { of ED visits were made on weekday, and } \\
52 \% \text { were made during daytime }(0800- \\
1600 \text { hrs). CTAS scores from } 1-5 \text { were } 1.7 \% \text {, } \\
28.4 \%, 51.6 \%, 14.7 \% \text { and } 3.6 \% \text { respectively. } \\
40 \% \text { of patients hospitalized. } \\
\sim 1 \% \text { increase in ED visits for every } 5 \text {-point } \\
\text { increase in total ESAS score. } \\
\text { Constitutional symptoms associated with } \\
\text { high odds of ED presentation. }\end{array}$ & $\begin{array}{l}\text { Overrepresentation of } \\
\text { lung cancer patients (who } \\
\text { have shorter survival } \\
\text { compared to overall cancer } \\
\text { population) reflecting the } \\
\text { original recruitment effort } \\
\text { for this initiative. } \\
\text { Unable to determine } \\
\text { where a patient was in the } \\
\text { trajectory of their illness. } \\
\text { Results may reflect effects } \\
\text { of ESAS tool itself } \\
\text { No comparison data for } \\
\text { patients NOT assessed } \\
\text { with ESAS (i.e., prior to } \\
\text { intervention, what were } \\
\text { ED visit rates within } 7 \text { days } \\
\text { of non-ESAS assessment?) }\end{array}$ \\
\hline $\begin{array}{l}\text { Brooks } \\
\text { et al. } \\
\text { (2016) } \\
\text { USA }\end{array}$ & $\begin{array}{l}\text { To evaluate the } \\
\text { effectiveness of reducing } \\
\text { hospitalization for } \\
\text { cancer patients requiring } \\
\text { outpatient acute care } \\
\text { by embedding a medical } \\
\text { oncologist in the ED } \\
\text { during evening hours } \\
\text { (5-11pm, Sunday to } \\
\text { Friday. } \\
\end{array}$ & $\begin{array}{l}\text { Quantitative } \\
\text { quasiexperimental } \\
\text { preintervention/ } \\
\text { post-intervention } \\
\text { study design. } \\
\text { Pilot intervention } \\
\text { examined data } 5 \\
\text { weeks pre- and } \\
\text { postintervention. }\end{array}$ & $\begin{array}{l}n=808 \text { eligible ED } \\
\text { visits by solid tumor } \\
\text { malignancies (mean }=11.5 \\
\text { ED visits } / \text { day). } \\
n=390 \text { visits } \\
\text { preintervention and } \\
n=418 \text { visits during } \\
\text { intervention. }\end{array}$ & $\begin{array}{l}\text { Intervention associated with a } \\
\text { nonsignificant difference in hospital } \\
\text { admissions }(p=0.62) \text {. } \\
\text { Study suggested that early oncologist } \\
\text { involvement led to improved care } \\
\text { coordination for cancer patients after initial } \\
\text { ED presentation. } \\
\text { Study demonstrated that } 37 \% \text { of oncology } \\
\text { ED visits occur } 8-4 p m \text { while } 31 \% \text { occur } \\
4-11 \text { pm. }\end{array}$ & $\begin{array}{l}\text { Pilot intervention } \\
\text { occurred over short period } \\
\text { of time. } \\
\text { Inclusion of subjective } \\
\text { assessment data amongst } \\
\text { many oncologists. } \\
\text { Low generalizability. }\end{array}$ \\
\hline $\begin{array}{l}\text { Livingston } \\
\text { et al. (2011) } \\
\text { Australia }\end{array}$ & $\begin{array}{l}\text { To understand key } \\
\text { characteristics of ED } \\
\text { visits among newly } \\
\text { diagnosed cancer } \\
\text { patients undergoing } \\
\text { chemotherapy in } \\
\text { outpatient setting. }\end{array}$ & $\begin{array}{l}\text { Quantitative } \\
\text { retrospective } \\
\text { chart audit of } 443 \\
\text { randomly selected, } \\
\text { newly diagnosed } \\
\text { cancer patients } \\
\text { who received } \\
\text { chemotherapy } \\
\text { through day } \\
\text { oncology and } \\
\text { presented to ED in } \\
2007 .\end{array}$ & $\begin{array}{l}n=443 \text { random patient } \\
\text { charts (Total day oncology } \\
\text { cancer patient charts in } \\
2007=2,380 ; 32.5 \% \\
\text { (772) visited ED at least } \\
\text { once). } \\
\text { Of } 443 \text {, slightly more } \\
\text { males than female patients } \\
\text { and mean age } 61 \text { years old. }\end{array}$ & $\begin{array}{l}\text { Triage categories of } 443 \text { ED visits: CTAS } 1 \\
=0.5 \%, \text { CTAS } 2=21.6 \% \text {, CTAS } 3=48.0 \% \text {, } \\
\text { CTAS } 4=27.5 \% \text { and CTAS } 5=2.3 \% \text {; over } \\
60 \% \text { of CTAS } 4 \& 5 \text { discharged home. } \\
\text { ED wait times ranged from Omin }-6.8 \mathrm{hrs} ; \\
\text { median ED length of stay } 6.3 \mathrm{hrs} \text {. } \\
\text { Chief complaints: febrile neutropenia, N\&V } \\
\text { and abdominal pain. } \\
67.3 \% \text { of ED visits occurred } \\
0600-1800 \text { hrs. } \\
58 \% \text { of ED visits resulted in hospitalization } \\
\text { and median length of stay was } 4.7 \text { days. }\end{array}$ & $\begin{array}{l}\text { Study limited by } \\
\text { actual data collected } \\
\text { electronically. }\end{array}$ \\
\hline
\end{tabular}




\begin{tabular}{|c|c|c|c|c|c|}
\hline $\begin{array}{l}\text { Authors } \\
\text { (Year) } \\
\text { Location }\end{array}$ & Purpose of Study & Study Design & Sample & Study Findings & Limitations \\
\hline $\begin{array}{l}\text { Mayer } \\
\text { et al. (2011) } \\
\text { USA }\end{array}$ & $\begin{array}{l}\text { To provide a population- } \\
\text { based snapshot of } \\
\text { ED visits by patients } \\
\text { with cancer in North } \\
\text { Carolina in an effort to } \\
\text { improve quality cancer } \\
\text { care and avoid ED visits. }\end{array}$ & $\begin{array}{l}\text { Quantitative } \\
\text { retrospective } \\
\text { review of the North } \\
\text { Carolina Disease } \\
\text { Event Tracking } \\
\text { and Epidemiologic } \\
\text { Collection Tool (NC } \\
\text { DETECT) related } \\
\text { to ED visits made in } \\
2008 \text { by patients } \\
\text { with cancer. }\end{array}$ & $\begin{array}{l}n=37,760 \text { ED visits by } \\
27,644 \text { patients with } \\
\text { cancer out of } 4,190,911 \\
\text { total ED visits in North } \\
\text { Carolina. }\end{array}$ & $\begin{array}{l}\text { More than half of all visits occurred on } \\
\text { weekends or evenings and } 44.9 \% \text { occurred } \\
\text { during normal office hours. } \\
\text { Top three complaints were pain, respiratory } \\
\text { distress and Gl issues. } \\
63.2 \% \text { of ED visits resulted in } \\
\text { hospitalization. }\end{array}$ & $\begin{array}{l}\text { NC DETECT database } \\
\text { not completely reliable } \\
\text { since secondary data (i.e., } \\
\text { may have missed some } \\
\text { cancer-related visits or } \\
\text { included other visits that } \\
\text { were not cancer-related). } \\
\text { Race and ethnicity data } \\
\text { not captured thereby } \\
\text { limiting generalizability } \\
\text { and prohibiting analysis of } \\
\text { these variables. } \\
\text { Unable to identify } \\
\text { whether patients visited } \\
\text { multiple hospitals. } \\
\text { Included patients from age } \\
5 \text { to } 90+\text {. }\end{array}$ \\
\hline $\begin{array}{l}\text { McKenzie } \\
\text { et al. (2011) } \\
\text { Australia }\end{array}$ & $\begin{array}{l}\text { To identify the nature } \\
\text { and magnitude } \\
\text { of chemotherapy } \\
\text { outpatients' unplanned } \\
\text { presentations and } \\
\text { admissions to ED and/or } \\
\text { cancer centre at a large } \\
\text { metropolitan tertiary } \\
\text { hospital, and to explore } \\
\text { the antecedents to } \\
\text { those presentations. }\end{array}$ & $\begin{array}{l}\text { Quantitative } \\
\text { retrospective data } \\
\text { were collected for } \\
\text { outpatients who } \\
\text { made an unplanned } \\
\text { hospital presentation } \\
\text { during a 12-month } \\
\text { period. Detailed } \\
\text { information was also } \\
\text { collected for those } \\
\text { outpatients' who had } \\
\text { received cytotoxic } \\
\text { chemotherapy at } \\
\text { the hospital's cancer } \\
\text { centre } 6 \text { months } \\
\text { prior to unplanned } \\
\text { hospital (ED or } \\
\text { cancer centre) } \\
\text { presentation. }\end{array}$ & $\begin{array}{l}n=233 \text { cancer } \\
\text { outpatients who received } \\
\text { chemotherapy in past } \\
6 \text { months made } 363 \\
\text { unplanned presentations to } \\
\text { either the cancer centre or } \\
\text { ED. } 518 \text { outpatients are } \\
\text { treated with chemotherapy } \\
\text { annually, therefore } 45 \% \\
\text { ( } 233 \text { outpatients) made } \\
\text { unplanned presentations. }\end{array}$ & $\begin{array}{l}87.6 \% \text { of the } 363 \text { unplanned presentations } \\
\text { resulted in hospital admissions with median } \\
\text { lengths of stay of } 5 \text { days. } \\
\text { Most frequent presentation symptoms } \\
\text { were: } N \& V \text {, pain, fever, SOB and } \\
\text { dehydration. } \\
\text { Chemotherapy outpatients delay seeking } \\
\text { help for treatment side effects for } 2-7 \text { days } \\
\text { for multiple reasons. }\end{array}$ & $\begin{array}{l}\text { Results may only be } \\
\text { generalizable to similar } \\
\text { sized cancer centres and } \\
\text { health care systems (i.e., } \\
\text { public vs private). ED } \\
\text { and cancer centre wait } \\
\text { times for chemotherapy } \\
\text { outpatients would also } \\
\text { impact antecedents to } \\
\text { unplanned presentations. }\end{array}$ \\
\hline $\begin{array}{l}\text { Prystajecky } \\
\text { et al. } \\
\text { (2012) } \\
\text { Canada }\end{array}$ & $\begin{array}{l}\text { To examine the } \\
\text { characteristics of ED } \\
\text { utilization by adult } \\
\text { cancer patients. }\end{array}$ & $\begin{array}{l}\text { Quantitative, } \\
\text { prospective cohort } \\
\text { of adult cancer } \\
\text { patients referred to a } \\
\text { tertiary care cancer } \\
\text { centre between July } \\
2007 \text { and March } \\
2009, \text { followed } \\
\text { until September } \\
2011 . \text { Variables } \\
\text { evaluated included } \\
\text { basic demographics, } \\
\text { ED visit rates, mode } \\
\text { of arrival, consults } \\
\text { ordered, admission } \\
\text { rates, and ED } \\
\text { diagnoses. }\end{array}$ & $\begin{array}{l}\text { Approached 6,772 cancer } \\
\text { patients, 4,329 (64\%) } \\
\text { participated. }\end{array}$ & $\begin{array}{l}1,881 \text { patients made } 4,623 \text { ED visits } \\
\text { between July } 2007 \text { and September } 2011 ; \\
45 \% \text { made } 1 \text { visit, } 47 \% \text { made } 2-5 \text { visits } \\
\text { and } 8 \% \text { made } \geq 6 \text { visits. Frequency of } \\
\text { CTAS scores were } 1 \%, 41 \%, 50 \%, 7 \% \text {, and } \\
1 \% \text {, for scores of } 1-5 \text { respectively. } 40 \% \\
\text { of visits resulted in hospital admission. } \\
\text { Most common diagnoses were intestinal } \\
\text { obstruction ( } 3.1 \%) \text {, chest pain ( } 2.3 \%) \text {, } \\
\text { fever ( } 2.3 \%) \text {, abdominal pain ( } 2.2 \%) \text {, and } \\
\text { pneumonia ( } 2.2 \%) \text {. Initiation of daytime } \\
\text { telephone triage service and patient access } \\
\text { to oncologists after-hours, monthly ED } \\
\text { presentations fell } 32 \% \text { between January and } \\
\text { April } 2009 \text {. }\end{array}$ & $\begin{array}{l}\text { Conference abstract } \\
\text { with limited details on } \\
\text { study parameters. Most } \\
\text { common diagnoses } \\
\text { indicate a high diversity } \\
\text { in presenting symptoms, } \\
\text { and lack of commonality. } \\
\text { Results may only be } \\
\text { generalizable to other } \\
\text { tertiary care cancer } \\
\text { centres of similar size. }\end{array}$ \\
\hline $\begin{array}{l}\text { van der } \\
\text { Meer et al. } \\
\text { (2015) } \\
\text { Australia }\end{array}$ & $\begin{array}{l}\text { To improve } \\
\text { understanding around } \\
\text { the specific needs } \\
\text { of cancer patients } \\
\text { visiting EDs. ED visits } \\
\text { and hospitalization } \\
\text { characteristics for } \\
\text { cancer patients were } \\
\text { compared with patients } \\
\text { not diagnosed with } \\
\text { cancer. }\end{array}$ & $\begin{array}{l}\text { Quantitative } \\
\text { descriptive, } \\
\text { retrospective, } \\
\text { multicenter cohort } \\
\text { study using hospital } \\
\text { administrative } \\
\text { data. Outcomes } \\
\text { of interest: level } \\
\text { of acuity, ED and } \\
\text { inpatient length of } \\
\text { stay, re-presentation } \\
\text { rates and admission } \\
\text { rates amongst } \\
\text { cancer and non- } \\
\text { cancer patients. }\end{array}$ & $\begin{array}{l}n=529,377 \text { ED visits } \\
\text { over } 36 \text { months to four } \\
\text { metropolitan hospitals in } \\
\text { Melbourne. } \\
2.4 \%(n=12,489) \\
\text { of all ED visits were } \\
\text { cancer-related. }\end{array}$ & $\begin{array}{l}\text { Compared with all other ED patient visits, } \\
\text { cancer-related visits had higher acuity } \\
\text { levels, and required longer management } \\
\text { time and length of stay in ED. Statistically } \\
\text { significant rates of re-presentation ( } 64 \\
\text { vs } 33 \%, p<0.001) \text {, hospitalization ( } 90 \text { vs } \\
46 \%, p<0.001) \text {, hospital lengths of stay } \\
\text { (5.6 vs } 2.8 \text { days, } p<0.001 \text { ) and inpatient } \\
\text { mortality }(7.9 \text { vs } 1.0 \%, p<0.001) \text {. } \\
\text { Main presenting complaints: pain, } \\
\text { respiratory symptoms, neurological } \\
\text { symptoms and fever. } \\
\text { CTAS } 1=1.2 \%, \text { CTAS } 2=14.5 \% \text {, CTAS } 3 \\
=51.8 \%, \text { CTAS } 4=31.0 \% \text { and CTAS } 5= \\
1.5 \% \text {. }\end{array}$ & $\begin{array}{l}\text { Retrospective, electronic } \\
\text { data collection prevents } \\
\text { control of patient } \\
\text { characteristics being } \\
\text { assessed. } \\
\text { Unable to delineate } \\
\text { advanced cancer patients } \\
\text { receiving palliative } \\
\text { treatment from relatively } \\
\text { well patients receiving } \\
\text { treatment for curative } \\
\text { intent, thereby potentially } \\
\text { skewing overall outcomes. }\end{array}$ \\
\hline
\end{tabular}




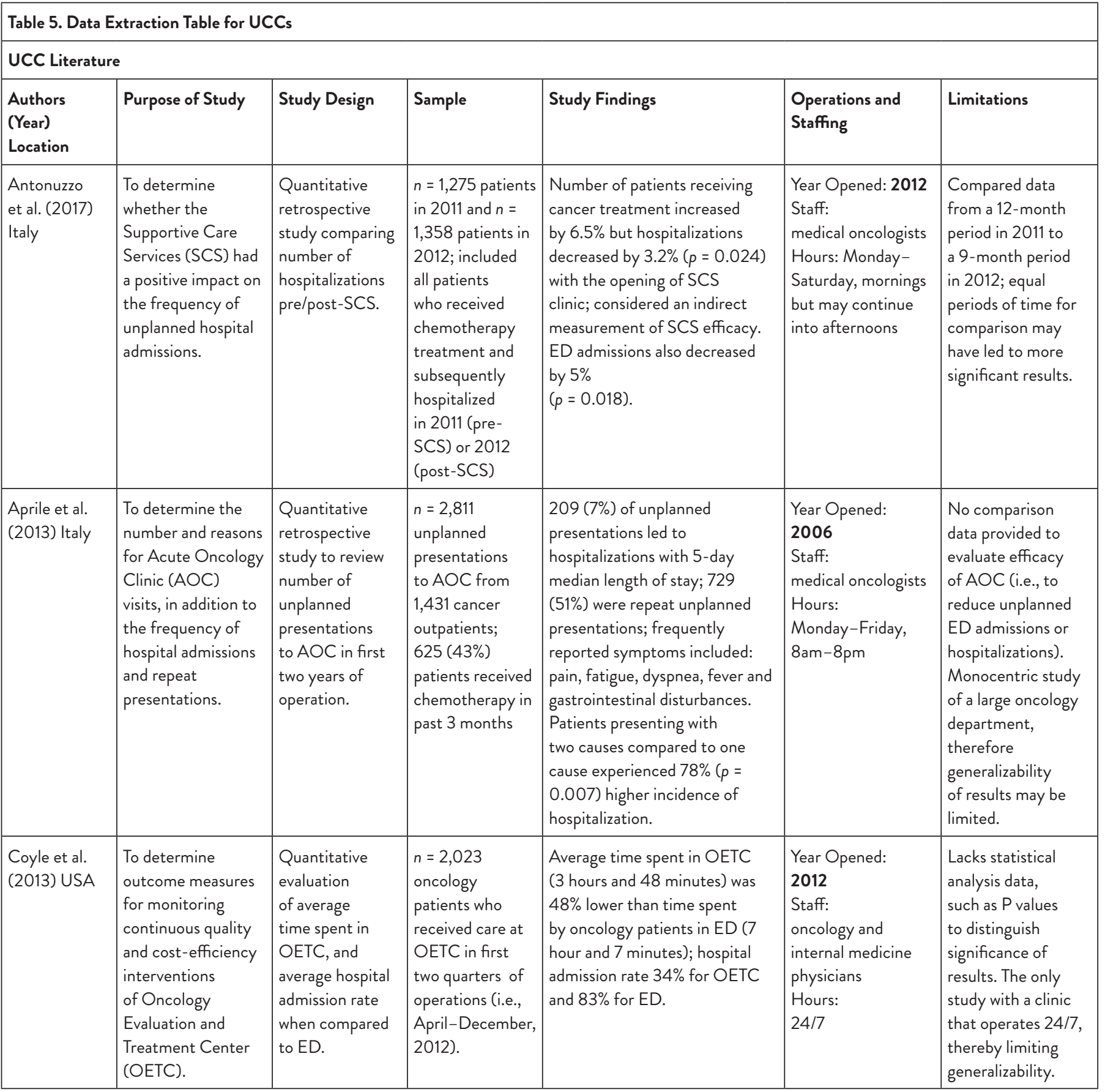




\begin{tabular}{|c|c|c|c|c|c|c|}
\hline $\begin{array}{l}\text { Kuo et al. } \\
\text { (2017) } \\
\text { Australia }\end{array}$ & $\begin{array}{l}\text { To evaluate the } \\
\text { delivery of timely } \\
\text { advice and cancer } \\
\text { care for patients } \\
\text { within the Rapid } \\
\text { Assessment Clinic } \\
(R A C) \text { vs ED. }\end{array}$ & $\begin{array}{l}\text { Quantitative } \\
\text { retrospective } \\
\text { review of clinical } \\
\text { records from } \\
\text { September, } \\
2013 \text {-June, } \\
2014 \text { for both } \\
\text { RAC and ED. }\end{array}$ & $\begin{array}{l}\text { RAC evaluated } \\
n=217 \text { patients } \\
\text { receiving } \\
\text { chemotherapy } \\
\text { while ED } \\
\text { evaluated } n= \\
287 \text { patients } \\
(152 \text { of these } \\
\text { patients received } \\
\text { chemotherapy } \\
\text { and were eligible } \\
\text { for review at } \\
\text { RAC). }\end{array}$ & $\begin{array}{l}\text { RAC compared to ED had } \\
\text { significantly shorter times spent } \\
\text { for review ( } 3.1 \text { vs } 9.7 \text { hours, } \\
p<0.00001 \text { ) and lower hospital } \\
\text { admission rates ( } 14.3 \% \text { vs } 69.1 \% \text {, } \\
p<0.00001) \text { with shorter } \\
\text { lengths of stay ( } 6.5 \text { vs } 9.5 \text { days, } \\
p=0.013 \text { ). }\end{array}$ & $\begin{array}{l}\text { Year Opened: } \\
2013 \\
\text { Staff: } \\
\text { medical oncology } \\
\text { advanced trainee } \\
\text { registrar and } \\
\text { oncology nurse; } \\
\text { combined with } \\
\text { telephone triage } \\
\text { nursing } \\
\text { Hours: } \\
\text { Days of week not } \\
\text { specified, 9am-5pm }\end{array}$ & $\begin{array}{l}\text { Wait times for } \\
\text { medical review } \\
\text { at RAC had } \\
\text { incomplete } \\
\text { documentation, } \\
\text { resulting in data } \\
\text { exclusion from } \\
\text { analysis as reflected } \\
\text { by wide confidence } \\
\text { interval. Small } \\
\text { sample size- } \\
\text { reliability and } \\
\text { accuracy of results } \\
\text { would benefit from a } \\
\text { longer retrospective } \\
\text { review period. }\end{array}$ \\
\hline $\begin{array}{l}\text { Meisenberg } \\
\text { et al. (2014) } \\
\text { USA }\end{array}$ & $\begin{array}{l}\text { To measure the } \\
\text { disposition of } \\
\text { patients from } \\
\text { Supportive Care } \\
\text { Clinic (SCC) in } \\
\text { comparison to ED, } \\
\text { and SCC effect } \\
\text { on ED visits and } \\
\text { hospital admissions } \\
\text { for cancer symptom } \\
\text { management. }\end{array}$ & $\begin{array}{l}\text { Quantitative } \\
\text { retrospective } \\
\text { review of patients } \\
\text { attending SCC } \\
\text { from inception in } \\
\text { June } 2012 \text { for } 11 \\
\text { months. }\end{array}$ & $\begin{array}{l}n=340 \text { visits } \\
\text { to SCC by } 330 \\
\text { unique patients } \\
\text { experiencing } \\
\text { cancer-related } \\
\text { symptoms. }\end{array}$ & $\begin{array}{l}\text { Admissions for symptom control } \\
\text { declined from } 39 \text { admissions to } \\
27 \text { per month, a reduction of } \\
31 \% \text {. Estimated prevention of } 66 \\
\text { ED visits. }\end{array}$ & $\begin{array}{l}\text { Year Opened: } \\
2012 \\
\text { Staff: } \\
\text { NP-led clinic } \\
\text { embedded within an } \\
\text { oncology practice; } \\
\text { first contact via } \\
\text { telephone triage or } \\
\text { on-call physician } \\
\text { afterhours } \\
\text { Hours: } \\
\text { Monday-Friday, no } \\
\text { later than 4:30 pm }\end{array}$ & $\begin{array}{l}\text { Patients were at } \\
\text { times assessed } \\
\text { next-day, thereby } \\
\text { not offering a } \\
\text { similar level of care } \\
\text { as ED. Reduction } \\
\text { of ED admissions } \\
\text { estimated rather } \\
\text { than measured. } \\
\text { Review period less } \\
\text { than } 12 \text { months and } \\
\text { small sample size } \\
\text { decreases reliability } \\
\text { of data. }\end{array}$ \\
\hline $\begin{array}{l}\text { Reugg (2013) } \\
\text { USA }\end{array}$ & $\begin{array}{l}\text { To describe an } \\
\text { NP-led Immediate } \\
\text { Care Center (ICC) } \\
\text { for patients and } \\
\text { compare the main } \\
\text { complaints managed } \\
\text { within the ICC } \\
\text { in both } 2010 \text { and } \\
2014 \text {. }\end{array}$ & $\begin{array}{l}\text { Quantitative } \\
\text { retrospective } \\
\text { review for quality } \\
\text { assurance. Data } \\
\text { reviewed for } \\
2004 \text { and } 2010 \\
\text { to track top } \\
\text { reasons patients } \\
\text { attended ICC. }\end{array}$ & $\begin{array}{l}n=3,634 \text { visits } \\
\text { to the ICC by } \\
\text { patients with } \\
\text { cancer in } 2004, \\
\text { and } n=3,009 \\
\text { visits to the ICC } \\
\text { by patients with } \\
\text { cancer in } 2010 .\end{array}$ & $\begin{array}{l}\text { In } 2004 \text {, top five visit reasons } \\
\text { were: dehydration ( } 35 \%), \\
\text { acute pain (17\%), anemia (12\%), } \\
\text { nausea and vomiting ( } 11 \%), \\
\text { dyspnea (10\%) and fever (6\%). } \\
\text { In } 2010 \text {, top five visit reasons } \\
\text { were: dehydration ( } 29 \%), \\
\text { dyspnea (12\%), pain (12\%), } \\
\text { gastrointestinal complaints } \\
\text { (10\% and fever ( } 5 \%) \text {. Patient } \\
\text { satisfaction monitored quarterly, } \\
\text { consistently above } 80 \% .\end{array}$ & \begin{tabular}{|l|} 
Year Opened: \\
2004 \\
Staff: \\
NP-led walk-in \\
environment; \\
primary oncology \\
team initially triages \\
patient calls \\
Hours: \\
Days of week not \\
specified; initially \\
an 8-hour unit \\
with one NP, now \\
a 16-hour unit with \\
three NPs
\end{tabular} & $\begin{array}{l}\text { ICC functions to } \\
\text { reduce unplanned } \\
\text { ED admissions and } \\
\text { hospitalizations } \\
\text { but study did not } \\
\text { evaluate efficacy } \\
\text { related to these } \\
\text { outcomes. Top five } \\
\text { visit reasons to ICC } \\
\text { only accounted } \\
\text { for } 425 \text { of } 3,634 \\
\text { visits in } 2004 \text { and } \\
412 \text { of } 3,009 \text { visits } \\
\text { in } 2010 \text { - vague } \\
\text { details provided in } \\
\text { relation to other } \\
\text { visit reasons. }\end{array}$ \\
\hline
\end{tabular}




\begin{tabular}{|c|c|c|c|c|c|c|}
\hline $\begin{array}{l}\text { Schlamb } \\
\text { (2014) } \\
\text { Canada }\end{array}$ & $\begin{array}{l}\text { To demonstrate } \\
\text { efficacy of Urgent } \\
\text { Cancer Care } \\
\text { (UCC) clinic in } \\
\text { first } 10 \text { months of } \\
\text { operation. }\end{array}$ & $\begin{array}{l}\text { Not a study - } \\
\text { retrospective } \\
\text { chart review for } \\
\text { newly operating } \\
\text { UCC clinic from } \\
\text { November } 2013 \\
\text { to September } \\
2014 \text {. }\end{array}$ & $\begin{array}{l}\text { Total patient } \\
\text { clinic and } \\
\text { Helpline volumes } \\
\text { to newly initiated } \\
\text { UCC clinic, } \\
\text { and patient } \\
\text { disposition upon } \\
\text { discharge. }\end{array}$ & $\begin{array}{l}\text { Over } 10 \text {-month period, patient } \\
\text { volume of } 2,966 \text { clinic and } \\
\text { Helpline; } 457 \text { patients ( } 41.5 \% \\
\text { increase) transferred to systemic } \\
\text { treatment area opposed to } \\
\text { hospital admission; } 110 \text { patients } \\
(0.25 \% \text { reduction) transferred } \\
\text { to ED; and } 6 \text { patients admitted } \\
\text { to hospital. }\end{array}$ & $\begin{array}{l}\text { Year Opened: } \\
2013 \\
\text { Staff: } \\
3 \text { registered nurses } \\
\text { alternating between } \\
\text { triage, assessment } \\
\text { and telephone } \\
\text { triage nurse roles; } 1 \\
\text { nurse practitioner/ } \\
\text { family physician in } \\
\text { oncology/ medical } \\
\text { oncologist } \\
\text { Hours: } \\
\text { Monday-Friday, } \\
\text { 9am-5pm }\end{array}$ & $\begin{array}{l}\text { Not a study but } \\
\text { rather collected } \\
\text { data parameters } \\
\text { presented in } \\
\text { PowerPoint format; } \\
\text { lacks statistical } \\
\text { analysis and } \\
\text { comparative analysis } \\
\text { with ED visits over } \\
\text { same period of data } \\
\text { collection. }\end{array}$ \\
\hline
\end{tabular}

Study data from UCC literature sources were extracted and summarized according to authors (year) and location, purpose of study, study design, sample, study findings, operations and staffing, and limitations. Patterns and themes were then identified from the extracted data, using iterative comparison methods, and formulated the final synthesis of results (Whittemore \& Knafl, 2005). This process was completed by the first author and reviewed with her thesis supervisor, the second author. Data from both extraction tables were compared and contrasted to identify the most frequently occurring patterns and themes to answer the first core question. The final thematic synthesis of results is presented below as three major themes and seven subthemes.

\section{DATA PRESENTATION}

\section{Search Results}

The 17 literature sources included in this integrative review demonstrated vast heterogeneity regarding both study methodology and research foci. Only two studies were qualitative (Clarke et al., 2015; Sitzes-Determann, 2009), and the majority $(n=12)$ relied on retrospective data collection methods (Antonuzzo et al., 2017; Aprile et al., 2013; Barbera et al., 2013; Kuo et al., 2017; Livingston et al., 2011; Majem et al., 2007;
Mayer et al., 2011; McKenzie et al., 2011; Meisenberg et al., 2014; Ruegg, 2013; Schlamb, 2014; van der Meer et al., 2016). Eight studies focused on ED utilization patterns (Barbera et al., 2013; Brooks et al., 2016; Clarke et al., 2015; Livingston et al., 2011; Mayer et al., 2011; McKenzie et al., 2011; Prystajecky et al., 2012; van der Meer et al., 2016) while another nine specifically focused on UCCs (Antonuzzo et al., 2017; Aprile et al., 2013; Coyle et al., 2013; Kuo et al., 2017; Majem et al., 2007; Meisenberg et al., 2014; Ruegg, 2013; Schlamb, 2014; Sitzes-Determann, 2009). Six studies originated in the United States (Brooks et al., 2016; Coyle et al., 2013; Mayer et al., 2011; Meisenberg et al., 2014; Ruegg, 2013; Sitzes-Determann, 2009), eight emerged from European countries (Antonuzzo et al., 2017; Aprile et al., 2013; Clarke et al., 2015; Majem et al., 2007) and Australia (Kuo et al., 2017; Livingston et al., 2011; McKenzie et al., 2011; van der Meer et al., 2016); and three reports originated in Canada (Barbera et al., 2013; Prystajecky et al., 2012; Schlamb, 2014). All studies were published between 2007 to 2017 with the majority $(n=11)$ occurring in the past five years (Antonuzzo et al., 2017; Aprile et al., 2013; Barbera et al., 2013; Brooks et al., 2016; Clarke et al., 2015; Coyle et al., 2013; Kuo et al., 2017; Meisenberg et al., 2014; Ruegg, 2013; Schlamb, 2014; van der Meer et al., 2016). 
Quality review. A considerable weakness noted amongst all studies was lack of prospective data collection to ensure adequate measurement of desired variables. In fact, only two studies did not rely exclusively on retrospective data (Brooks et al., 2016; Clarke et al., 2015). Being unable to obtain specific variable measurements became apparent when no studies were found to directly measure the effects of initiating a UCC on either the rates of ED and hospital admissions, or the direct savings associated with this change in care delivery.

\section{Comparing ED and UCC Outpatient Acute Cancer Symptom Management}

The first core research question for this integrative review was: What is the state of the science regarding UCCs and what differences exist when compared to EDs in the management of outpatient acute cancer symptoms?

The findings presented in Tables 4 and 5 helped identify dominant areas of research with regards to outpatient acute cancer symptom management within EDs and UCCs, as well as any existing gaps in research studies or scientific literature. Cost-effectiveness, improved safety, and patient-centred care were the three major themes that emerged during data analysis and synthesis when comparing management of outpatient acute cancer symptoms within the two different healthcare settings. The next section of the paper will narratively present results pertinent to the initial core question, identifying themes and subthemes from the reviewed literature.

\section{Cost-effective approach to cancer care.}

Urgent cancer clinics. The introduction of UCCs has demonstrated cost-effectiveness by reducing unplanned ED visits and hospitalizations. A US-based study estimated preventing 66 ED visits (Meisenberg et al., 2014) while four other studies implied decreased ED visits as a result of introducing UCCs (Aprile et al., 2013; Kuo et al., 2017; Majem et al., 2007; Ruegg, 2013). Within Canada, an online report indicated that Winnipeg's Urgent Cancer Care Clinic evaluated 3,000 patients over 10 months - presumably diverting these patients away from overcrowded EDs (Schlamb, 2014). A major weakness for this Canadian report and the five other studies cited above was lack of comparative data from EDs to determine whether these UCCs were successful at directly reducing acute cancer symptom ED visits. In contrast, researchers in Italy established a direct correlation and a clinically significant reduction in ED visits of 5\% within the first 12 months of operating their UCC (Antonuzzo et al., 2017).

Hospitalization reductions were highly variable ranging from a 3.2\% reduction (Antonuzzo et al., 2017) to a $54.8 \%$ reduction (Kuo et al., 2017) with associated hospital length of stay reductions of $15.1 \%$ and $42.9 \%$, respectively. Coyle et al. (2013) commented on the differences between UCC and ED hospital admission rates $-34 \%$ versus $83 \%$ respectively, but clinical significance was not stated. Of final interest, Majem et al. (2007) noted that $49 \%$ of UCC patients were hospitalized, which suggests that although ED visits may be avoided, hospitalization was inevitable for some patients based on their presenting symptoms.
Improved ED utilization. Analysis of CTAS scores helps identify acute cancer symptoms which are better managed within cost-effective ambulatory settings, especially CTAS scores (see Table 1) that are three or greater (i.e. target treatment time of 30 minutes or longer). In the literature, CTAS categories frequently represented by patients with cancer who sought ED care were levels three and four. This is reported as $57-66.3 \%$ in Canadian studies (Barbera et al., 2013; Prystajecky et al., 2012) and 75.5-82.8\% in Australian studies (Livingston et al., 2011; van der Meer et al., 2016). Emergency department use should be reserved for life-threatening or emergent symptoms whenever possible to limit overcrowding from inappropriate symptom presentation. The Canadian studies also showed a high proportion of level two CTAS scores with $28.4-41 \%$ of the ED visits made by patients with cancer (Barbera et al., 2013; Prystajecky et al., 2012). Level one and two CTAS scores target treatment times of less than 15 minutes and represent appropriate utilization of ED services.

Optimizing oncology provider roles. Brooks et al. (2016) observed the effects of embedding an oncologist within an ED during evening hours. Although innovative, this approach was found to be neither cost-effective nor beneficial in decreasing ED or hospital admission rates (Brooks et al., 2016). Subjectively, the participating oncologists stated that $27 \%$ of ED visits could be managed in ambulatory settings without ED management, and 19\% of hospital admissions were considered potentially avoidable (Brooks et al., 2016). In contrast, UCCs that utilize oncology nurse practitioners support cost-effective care with lower consultation fees by reducing oncologist visits and interrupted chemotherapy protocols (Meisenberg et al., 2014; Ruegg, 2013).

\section{Improved safety for patients with cancer.}

Focused oncology expertise. The majority of patients diagnosed with cancer will face fragmented care pathways due to care often being given by multiple institutions and departments within a cancer centre. This complexity can negatively affect safety and quality of care (Brooks et al., 2016). The introduction of UCCs minimizes fragmented care, improves continuity of cancer care, and boasts a significant time differential for the initiation of antibiotics in patients with neutropenic fever. As demonstrated by Ohio's UCC, the difference in antibiotic administration time was a few minutes compared with an average 1.7 hours within EDs (Ruegg, 2013). Similarly, the overall time spent in a UCC was $48 \%$ lower than time spent in an ED according to Coyle et al. (2013). This significant difference equates to an average total time spent on patient review of 3.1 hours in a UCC compared to 9.7 hours in an ED (Kuo et al., 2017). Brooks et al. (2016) also suggested that early oncologist involvement after initial cancer symptom presentation led to improved care coordination for patients - an additional safety benefit of UCCs. Lower hospital admission rates for UCCs (34\%) compared to EDs (83\%) were also associated with decreased risk of mortality and increased quality of life (Coyle et al., 2013). Finally, UCCs were associated with shorter hospital admission lengths of stay for patients with cancer when compared to EDs (Antonuzzo et al., 2017; Kuo et al., 2017; Meisenberg et al., 2014). 
Patient perception of EDs. Another area of concern regarding safety involved patients' reluctance to attend EDs. McKenzie et al. (2011) cited several reasons for this potential resistance including not wanting to inconvenience busy staff, difficulty accessing the ED, long wait times once they arrive at the ED, and optimism that their symptoms will subside independently. Some studies demonstrated that patients will deny their symptoms to avoid potential hospital admission due to previous negative experiences, or to avoid the unknown in the ED (Clarke et al., 2015; Sitzes-Determann, 2009). As described in the literature, patients felt that ED staff relied heavily on them to provide information related to their cancer diagnosis and treatment (Sitzes-Determann, 2009). The authors attributed this ED staff reliance to lack of medical record accessibility between medical facilities, which led to decreased perceived safety for patients accessing EDs for acute cancer symptom management (Sitzes-Determann, 2009).

\section{Higher quality, patient-centred care.}

Understanding cancer symptoms. Higher-quality care involves meeting both the known and potential needs of patients. A Canadian study by Barbera et al. (2013) demonstrated the effectiveness of predicting ED visits by monitoring patient-reported symptom scores from the Edmonton Symptom Assessment System tool utilized at routine oncology visits. Several assessed symptoms (e.g., pain, lack of well-being, nausea, drowsiness, shortness of breath) were associated with ED visits within one week of the symptom assessment (Barbera et al., 2013). Results also demonstrated that "constitutional symptoms were associated with even higher odds of ED usage" (p. 427), suggesting poor utilization of ambulatory setting resources (Barbera et al., 2013).

Expanded cancer services. Ambulatory cancer centres across the continents report operating Monday to Friday with daytime business hours. Three studies reported on the most frequent time of day that patients with cancer utilized EDs, confirming more than half of all visits occurred during weekday, daytime hours (Barbera et al., 2013; Livingston et al., 2011; Mayer et al., 2011). Brooks et al. (2016) emphasized oncology outpatient services will also need to offer longer hours of operation such as late afternoon or early evening. Four of the seven UCCs offer expanded accessibility by extending hours of operation into the evenings (Aprile et al., 2013; Majem et al., 2007; Ruegg, 2013) while two USA centres boast expanded 24/7 UCCs (Coyle et al., 2013). Of the seven UCCs, only one UCC did not consistently offer same-day appointments (Meisenberg et al., 2014). An ambulatory setting may also have greater capacity to offer sameday specialized procedures such as therapeutic thoracenteses or paracenteses (Brooks et al., 2016). At Ohio's UCC, NPs successfully perform these procedures and discharge patients home a few hours later (Ruegg, 2013). These procedures are also performed by physicians in Spain's UCC (Majem et al., 2007).

\section{Existing UCC Operations}

The second core research question addressed in this integrative review was: Where do UCCs exist around the world, and what is understood about UCCs related to clinic operations and staffing models?
Within the literature included in this review, nine UCCs were described in detail. These nine UCCs currently operate in various parts of the world including Spain (Majem et al., 2007), Canada (Schlamb, 2014), the USA (Coyle et al., 2013; Meisenberg et al., 2014; Ruegg, 2013; Sitzes-Determann, 2009), Italy (Antonuzzo et al., 2017; Aprile et al., 2013), and Australia (Kuo et al., 2017). The nine UCCs are outlined in Table 5 and demonstrate that clinic names, operations, and staffing are highly variable. Historically, the first clinic to open its doors was the Oncology Acute Toxicity Unit in 1999, which operates in Spain (Majem et al., 2007). The most recent clinics opened in 2013 including the Rapid Assessment Clinic in Australia (Kuo et al., 2017), and the Urgent Cancer Care Clinic in Winnipeg, Canada. Six UCCs are staffed with medical oncologists (Antonuzzo et al., 2017; Aprile et al., 2013; Coyle et al., 2013; Kuo et al., 2017; Majem et al., 2007; Schlamb, 2014) while the remaining three utilize oncology nurse practitioners (Meisenberg et al., 2014; Ruegg, 2013; Sitzes-Determann, 2009); most clinics also rely on registered nurse support. The hours of operation amongst all UCCs were variable and ranged from morning hours only (Antonuzzo et al., 2017) to regular daytime business hours (Kuo et al., 2017; Majem et al., 2007; Meisenberg et al., 2014; Schlamb, 2014), as well as 12-hour (Aprile et al., 2013), 16-hour (Ruegg, 2013), or 24-hour (Coyle et al., 2013; Sitzes-Determann, 2009) clinic operations. Most UCCs operate during weekdays but one UCC offers Saturday service (Antonuzzo et al., 2017) and two others run seven days a week (Coyle et al., 2013; Sitzes-Determann, 2009). Finally, five UCCs (Kuo et al., 2017; Majem et al., 2007; Meisenberg et al., 2014; Ruegg, 2013; Schlamb, 2014) mentioned utilizing telephone triage as the initial contact method with potential patients prior to visitation. Telephone triage helps prevent inappropriate patient symptom presentations and plans to either manage the symptom at home with telephone support or visit within an EDs (Kuo et al., 2017; Meisenberg et al., 2014).

\section{DISCUSSION}

The aim of this integrative literature review was to answer two core questions: 1 ) What is the state of the science regarding UCCs, and what differences exist when compared to EDs in the management of outpatient acute cancer symptoms?; and 2) Where do UCCs exist around the world, and what is understood about UCCs related to clinic operations and staffing models? Three major themes emerged from the data in response to the first core questions including cost-effectiveness, improved safety, and patient-centred care. The second core question identified where UCCs are currently operating around the world, and what staffing models are utilized by these UCCs.

Cost-effectiveness was achieved after introducing UCCs by reducing ED visits, hospital admissions, and when applicable, shorter lengths of stay in hospital (Antonuzzo et al., 2017; Aprile et al., 2013; Coyle et al., 2013; Kuo et al., 2017; Majem et al., 2007; Meisenberg et al., 2014; Ruegg, 2013; Schlamb, 2014). Providing care in an ambulatory setting also decreased overall costs associated with patient treatment. Likewise, patients experienced fewer cancer treatment interruptions or 
oncologist visits related to managing acute cancer symptoms within UCCs, which leads to indirect cancer expense reductions (Meisenberg et al., 2014; Ruegg, 2013). Specifically, oncology practitioners working within UCCs were better able to bridge the gaps between immediate patient needs, and ongoing cancer treatment due to their implicit familiarity with cancer centre processes. Finally, savings may be further increased by utilizing oncology specialized NPs within UCCs, as opposed to medical oncologists, without compromising patient safety or quality of care (Meisenberg et al., 2014; Ruegg, 2013).

Urgent cancer clinics also improved safety for patients with cancer by addressing patient experiences and perceptions related to ED utilization. Since UCCs reside in ambulatory cancer centres, access to patient medical records is immediate and clinic volumes are smaller in comparison to EDs, thereby improving both speed and coordination of care for patients with cancer (Brooks et al., 2016; Coyle et al., 2013; Kuo et al., 2017; Ruegg, 2013). While not directly studied, UCCs likely help negate some of the unfavourable patient perceptions associated with EDs such as heavy staff reliance on patients concerning their cancer diagnosis and treatment plan, or their experiences of denying symptoms to avoid long ED wait times or inconveniencing staff (Clarke et al., 2015; McKenzie et al., 2011; Sitzes-Determann, 2009). With fewer barriers existing, patients may seek earlier intervention at UCCs, which also contributes to safer care.

The final theme to emerge from this review suggested that UCCs provide higher quality, patient-centred care. Urgent cancer clinics offer same-day, unscheduled appointments similar to ED visits, but with the additional benefits of oncology experts who understand the full range of treatments across all cancer diagnoses, and clinical visits within a familiar place. As well, some UCCs have the added capacity to perform specialized outpatient procedures (i.e., thoracenteses or paracenteses), which helps meet and alleviate the acute, and sometimes palliative, needs of patients in a timely fashion (Brooks et al., 2016; Majem et al., 2007; Ruegg, 2013). Ultimately, the ability of UCCs to offer timely supportive care, and address constitutional symptoms sooner in contrast to EDs, will elevate overall quality of life for patients and families living with cancer (Barbera et al., 2013).

Although EDs historically provided a crucial service to patients experiencing acute cancer symptoms, continued use of this model of care for oncology patients remains costly and potentially lacks a safe, patient-centred approach to care for these individuals. Across the continents, healthcare efficiencies and expenditures are a top priority for both providers and patients. The advent of UCCs helps address both priorities. However, the sparse amount of available literature to support adopting this new model of care is problematic. Although the first documented UCC opened in 1999, clinical findings were not reported in the literature until 2007 (Majem et al., 2007). In the past decade, only eight other studies with a focus on UCCs were successfully identified (Antonuzzo et al., 2017; Aprile et al., 2013; Coyle et al., 2013; Kuo et al., 2017; Meisenberg et al., 2014; Ruegg, 2013; Schlamb, 2014; Sitzes-Determann, 2009). Based on these studies, UCCs offer an innovative alternative for providing ambulatory supportive symptom management with early evidence indicating enhanced patient care when compared to EDs.

\section{Limitations}

There were several methodological limitations that affected the findings in this integrative review. As a graduate nursing student, only the first author reviewed all identified literature, which increases potential bias. Similarly, the combination and complexity of integrating multiple methodologies can contribute to lack of rigour, and increase inaccuracy or bias (Whittemore \& Knafl, 2005). It is also acknowledged by Whittemore and Knafl (2005) that methods of analysis, synthesis, and drawing conclusions remain poorly developed for integrative reviews. However, the findings presented offer an introductory review of a unique and timely topic; specifically, supportive care within UCCs for outpatient acute cancer symptoms.

\section{Implications for Nursing Practice and Future Research}

Several practice implications for nursing arise from this integrative review. For instance, improving a patient's experience with cancer symptoms ought to start during routine oncology clinic visits with proper, detailed assessments and early management of poorly controlled symptoms (e.g., pain, respiratory distress, nausea or vomiting) frequently addressed in EDs (Barbera et al., 2013; Mayer et al., 2011; van der Meer et al., 2016). Specific symptoms including pain, nausea or shortness of breath, and constitutional symptoms such as well-being, fatigue, and appetite are predictable and associated with subsequent ED visits (Barbera et al., 2013). Therefore, the aforementioned specific symptoms should be targeted in outpatient settings by actively trialling prophylactic and preventative treatment strategies (Livingston et al., 2011), whereas constitutional symptoms may require psychosocial or dietary interventions, as well as goals of care conversations to help avoid potential ED visits. The possibility of predicting and preventing these common cancer-related adverse events was a strategy recommended by some researchers (Aprile et al., 2013; Barbera et al., 2013). The importance of reinforcing patient and caregiver education for self-care symptom management was also emphasized by van der Meer et al. (2016). Broadly speaking, patients and caregivers need clear, consistent, and unambiguous information about what to do if unwell or febrile after chemotherapy to prevent delays in seeking help for acute cancer symptoms (Clarke et al., 2015; McKenzie et al., 2011).

Providing telephone support was another intervention identified, and an important first measure, towards preventing potential ED visits for patients with cancer (Majem et al., 2007). Oncology nurses specially trained to correctly screen and triage telephone calls can help ensure patients receive appropriate care in the most ideal location (i.e., self-care at home versus in-person care at a family doctor, ED, or UCC). In turn this will help optimize health care resources (Meisenberg et al., 2014). As noted by Ruegg (2013), nurses and "nurse practitioners educated in oncology are specifically equipped to manage cancer-related issues before they become so severe that they necessitate hospitalization" (p. E55). Capitalizing 
on oncology nurses' strengths to manage acute cancer symptoms astutely will benefit all impacted stakeholders, especially patients and their caregivers.

With regards to future research implications, a focus on qualitative and prospective quantitative studies would strengthen existing evidence found in the literature. Research efforts dedicated to evaluating UCC efficacy and cost-effectiveness are needed to impact potential practice changes. Additionally, qualitative research exploring oncology healthcare providers' (i.e., registered nurses, nurse practitioners and physicians) experiences working in and managing UCCs, or the experiences of patients with cancer who are familiar with both models of care, remains absent from the literature. Future research is also needed to better understand UCC processes, while examining the real and potential barriers of operating these clinics. Finally, although UCCs exist within Canada, currently there are no Canadian peer-reviewed publications regarding this innovation. Continued UCC research, both in Canada and abroad, is imperative to impact successful transition from the current ED model of care for oncology patients towards the provision of exceptional outpatient acute cancer symptom management within UCCs.

\section{CONCLUSION}

Throughout this integrative review, three major themes emerged from the literature in response to the first core question. Additionally, the second core question resulted in identification of individual UCCs from around the world, their

\section{REFERENCES}

Antonuzzo, A., Vasile, E., Sbrana, A., Lucchesi, M., Galli, L., Brunetti, I. M., Musettini, G., Farnesi, A., Biasco, E., Virgili, N., Falcone, A., $\&$ Ricci, S. (2017). Impact of a supportive care service for cancer outpatients: Management and reduction of hospitalizations. Preliminary results of an integrated model of care. Supportive Care in Cancer, 25(1), 209-212. https://doi.org/10.1007/s00520-016-3403-z

Aprile, G., Pisa, F. E., Follador, A., Foltran, L., De Pauli, F., Mazzer, M., Lutrino, S., Sacco, C. S., Mansutti, M., \& Fasola, G. (2013). Unplanned presentations of cancer outpatients: A retrospective cohort study. Supportive Care in Cancer, 21(2), 397-404. https://doi. org/10.1007/s00520-012-1524-6

Barbera, L., Atzema, C., Sutradhar, R., Seow, H., Howell, D., Husain, A., Sussman, J., Earle, C., Liu, Y., \& Dudgeon, D. (2013). Do patient-reported symptoms predict emergency department visits in cancer patients? A population-based analysis. Annals of Emergency Medicine, 61(4), 427-437. https://doi.org/10.1016/j. annemergmed.2012.10.010

Brooks, G. A., Chen, E. J., Murakami, M. A., Giannakis, M., Baugh, C. W., \& Schrag, D. (2016). An ED pilot intervention to facilitate outpatient acute care for cancer patients. American Journal of Emergency Medicine, 34(10), 1934-938. https://doi.org/10.1016/j. ajem.2016.06.076

Canadian Cancer Statistics Advisory Committee. (2019). Canadian cancer statistics 2019. Canadian Cancer Society. https://www.cancer. ca/ /media/cancer.ca/CW/cancer\%20information/cancer\%20 101/Canadian\%20cancer\%20statistics/Canadian-Cancer-Statistics2019-EN.pdf?la=en

Clarke, R. T., Bird, S., Kakuchi, I., Littlewood, T. J., \& van Hamel Parsons, V. (2015). The signs, symptoms and help-seeking clinical operations and staffing models. The themes suggest that UCCs support care for oncology patients that is cost-effective, safer, higher quality, and patient-centred when compared to EDs. The state of the science for UCCs is growing but more research is necessary to ensure patient needs are appropriately met. To date there are no qualitative studies that focus on the experiences of oncology healthcare providers working within these clinics. Their experiences, in addition to a clear description of the processes involved with operating UCCs, must take precedence in future research efforts. The demand for an improved comprehensive understanding of UCC operations and experiences may help escalate universal adoption of ambulatory management for acute cancer symptoms. Minimizing acute, yet non-emergent, cancer visits to EDs is beneficial and helps ensure all patients sharing the same healthcare system receive "continuous high-quality care in the appropriate place, at the appropriate time, and with the right specialized expert oversight" (Young et al., 2016, p. 301).

\section{ACKNOWLEDGEMENTS}

This research was supported in part by the Alberta Cancer Foundation 2020 Marlene Mysak Oncology Staff Education Bursary, and 2019 Denise Melanson Bursary, as well as an Alberta Registered Nurses Educational Trust 2019 Annual Academic Scholarship.

experiences of neutropenic sepsis patients before they reach hospital: A qualitative study. Supportive Care in Cancer, 23(9), 26872694. https://doi.org/10.1007/s00520-015-2631-y

Colligan, E. M., Ewald, E., Keating, N. L., Parashuram, S., Spafford, M., Ruiz, S., \& Moiduddin, A. (2017). Two innovative cancer care programs have potential to reduce utilization and spending. Medical Care, 55(10), 873-878. https://doi.org/10.1097/ MLR.0000000000000795

Cooksley, T., \& Rice, T. (2017). Emergency oncology: Development, current position and future direction in the USA and UK. Supportive Care in Cancer, 25(1), 3-7. https://doi.org/10.1007/ s00520-016-3470-1

Coyle, Y. M., Miller, A. M., \& Paulson, R. S. (2013). Model for the costefficient delivery of continuous quality cancer care: A hospital and private-practice collaboration. Baylor University Medical Center Proceedings, 26(2), 9599. https://www.ncbi.nlm.nih.gov/ pubmed/23543960

Hassett, M. J., O’Malley, A. J., Pakes, J. R., Newhouse, J. P., \& Earle, C. C. (2006). Frequency and cost of chemotherapy-related serious adverse effects in a population sample of women with breast cancer. Journal of the National Cancer Institute, 98(16), 1108-1117. https://doi.org/10.1093/jnci/djj305

Kuo, J. C., De Silva, M., Diwakarla, C., \& Yip, D. (2017). A Rapid Access Clinic to improve delivery of ambulatory care to cancer patients. Asia-Pacific Journal of Clinical Oncology, 13(3), 179-184. https://doi. org/10.1111/ajco.12641

Livingston, P. M., Craike, M., \& Considine, J. (2011). Unplanned presentations to emergency departments due to chemotherapy 
induced complications: Opportunities for improving service delivery. Australasian Emergency Nursing Journal, 14(2), 62-68.

Majem, M., Galán, M., Pérez, F. J., Muñoz, M., Chicote, S., Soler, G., Navarro, M., Martínez-Villacampa, M., García del Muro, X., Dotor, E., Laquente, B., \& Germà, J. R. (2007). The Oncology Acute Toxicity Unit (OATU): An outpatient facility for improving the management of chemotherapy toxicity. Clinical and Translational Oncology, 9(12), 784-788.

Mason, H., DeRubeis, M. B., Foster, J. C., Taylor, J. M., \& Worden, F. P. (2013). Outcomes evaluation of a weekly nurse practitionermanaged symptom management clinic for patients with head and neck cancer treated with chemoradiotherapy. Oncology Nursing Forum, 40(6), 581-586. https://doi.org/10.1188/13.ONF.40-06AP

Mayer, D. K., Travers, D., Wyss, A., Leak, A., \& Waller, A. (2011). Why do patients with cancer visit emergency departments? Results of a 2008 population study in North Carolina. Journal of Clinical Oncology, 29(19), 2683-2688. https://doi.org/10.1200/ jco.2010.34.2816

McKenzie, H., Hayes, L., White, K., Cox, K., Fethney, J., Boughton, M., \& Dunn, J. (2011). Chemotherapy outpatients' unplanned presentations to hospital: A retrospective study. Supportive Care in Cancer, 19(7), 963-969. https://doi.org/10.1007/s00520-010-0913-y

Meisenberg, B. R., Graze, L., \& Brady-Copertino, C. J. (2014). A supportive care clinic for cancer patients embedded within an oncology practice. The Journal of Community and Supportive Oncology, 12(6), 205-208.

Prystajecky, M., Lang, E., Wang, D., Simon, J., Sinnarajah, A., Martin, T. L. W., Murray, A., Hagen, N., Waller, A., Bultz, B., Carlson, L., Groff, S., McRae, A., Thomas, B. (2012). Emergency department utilization by adult cancer patients: A prospective cohort study. Academic Emergency Medicine, 19, S225-S226.

Ruegg, T. A. (2013). A nurse practitioner-led urgent care center: Meeting the needs of the patient with cancer. Clinical Journal of Oncology Nursing, 17(4), E52-E57. https://doi.org/10.1188/13.CJON. E52-E57

Schlamb, T. (2014). Urgent cancer care and the cancer helpline. http:// www.cancercare.mb.ca/resource/File/MBWCN/presenations/ Urgent_Care_Presentation-Tracy_Schlamb.pdf
Sitzes-Determann, A. L. (2009). Planning for the sustainment of a 24/7 oncology clinic: An action and evaluation research project. (Doctoral dissertation). $\quad$ http://ezproxy.lib.ucalgary.ca/login?url=http:// search.ebscohost.com/login.aspx?direct=true\&db=rzh\&AN=10985 3890\&site $=$ ehost-live

Specialist Unit for Review of Evidence (SURE). (2018a). Questions to assist with the critical appraisal of cohort studies. https://www.cardiff. ac.uk/__data/assets/pdf_file/0006/1142997/SURE-CA-form-forCohort_2018.pdf

Specialist Unit for Review of Evidence (SURE). (2018b). Questions to assist with the critical appraisal of qualitative studies. https://www. cardiff.ac.uk/_data/assets/pdf_file/0007/1142971/SURE-CA-formfor-Qualitative_2018.pdf

Trip, K., Boloorchi, A., \& Berman, H. (2011). Utilizing the Canadian emergency department Triage and Acuity Scale (CTAS) in an oncology urgent care clinic: The university health network experience. Canadian Oncology Nursing Journal, 21(1), 52-57. https://www.ncbi.nlm.nih.gov/pubmed/21462878

van der Meer, D. M., Weiland, T. J., Philip, J., Jelinek, G. A., Boughey, M., Knott, J., Marck, C. H., Weil, J. L., Lane, H. P., Dowling, A. J., \& Kelly, A. M. (2016). Presentation patterns and outcomes of patients with cancer accessing care in emergency departments in Victoria, Australia. Supportive Care in Cancer, 24(3), 1251-1260. https://doi. org/10.1007/s00520-015-2921-4

Vandyk, A. D., Harrison, M. B., Macartney, G., Ross-White, A., \& Stacey, D. (2012). Emergency department visits for symptoms experienced by oncology patients: A systematic review. Supportive Care in Cancer, 20(8), 1589-1599. https://doi.org/10.1007/ s00520-012-1459-y

Whittemore, R., \& Knafl, K. (2005). The integrative review: updated methodology. Journal of Advanced Nursing, 52(5), 546-553. https:// doi.org/10.1111/j.1365-2648.2005.03621.x

Young, A., Marshall, E., Krzyzanowska, M., Robinson, B., Brown, S., Collinson, F., Seligmann, J., Abbas, A., Rees, A., Swinson, D., Neville-Webbe, H., \& Selby, P. (2016). Responding to acute care needs of patients with cancer: Recent trends across continents. The Oncologist, 21(3), 301-307. https://doi.org/10.1634/ theoncologist.2014-0341 